DOI: 10.33727/JRISS.2021.2.24:215-220

\title{
Deposit insurance and banking stability
}

\author{
Cyrine Snen ${ }^{1}$ \\ ${ }^{1}$ University of Manouba, Business School of Tunis, Tunis, Tunisia \\ E-mail: snencyrine@gmail.com
}

\begin{abstract}
Many countries provide extensive deposit insurance as a part of a safety net that promotes stability in the financial system. An unintended conequence of deposit insurance is that it reduces depositors' incentives to supervise banks, leading to excessive risk-taking. The article discussed the relationship between deposit insurance, bank risks and systemic vulnerabilities before and during the Great Financial Crisis.
\end{abstract}

Keywords: financial system, stability, risk-taking, deposit insurance, bank risk

\section{Introduction}

After the financial and economic crises that erupted in 2007-2009, it was observed that the financial sector in Europe was still vulnerable and did not function reliably. After the 2008 banking crisis, banks have been struggling for their future (Menrad, 2020).[1] Obviously, in the monetary union such as the Eurozone, problems caused by close links between public sector finance and the banking sector can easily transcend national borders and cause financial distress in all member states.

The subsequent eurozone sovereign debt crisis increased the difficulties for banks. The government bonds they held became risky assets (Golab et al., 2018).[2]

An effective institutional framework with a system capable of adapting to innovations and changes in the environment, as well as rigorous application by the control and supervisory authority of the standards for risk management, monitoring and coverage provided for in the prudential rules issued by the regulator, are necessary conditions for circumscribing and controlling risks and safeguarding the stability of the banking system.

In fact, all the possible dysfunctions noted at the level of the main infrastructures of the financial services sector such as the payment systems, the data exchange system, the functioning of the money market, the recourse to the refinancing of the central bank as well as the intervention of the supervisory and regulatory authorities in the control of the procedures and the systems set up, can present real vectors of destabilization of the banking system.

In world practice, the establishment of a deposit insurance system has become a tool to solve the problems of maintaining the stability of the banking system, increasing customer confidence in banks and other credit institutions, and preventing large-scale withdrawals of deposits during economic crises (Kuznichenko et al., 2021).[3]

In response to the global financial crisis, some countries have substantially increased the coverage of financial safety nets to restore market confidence and avoid potential contagious runs in the banking industry (Demirgüç-Kunt et al., 2014).[4]

This has once again sparked controversy about the impact of deposit insurance on the stability and performance of the banking industry. Although previous research has shown that deposit insurance will exacerbate the moral hazard problem in bank loans and is associated with a higher probability of bank crises (Demirguc-Kunt and Detragiache 2002),[5] as far as we know, there is no research to 
examine the impact of deposit insurance Banking risks and stability during periods of global financial instability.

Bank's risk-taking may reduce by the proper supervision of banking regulators (Demirguc-Kunt et al., 2014). Therefore, banking policymakers design the supervision which improves the bank's soundness and strengthen the financial development of a country.

According to the Barth, et al., (2013),[6] fifty-five deposit insurance adopted countries have two parallel regulatory institutes for surveillance of banks' actions. banks are supervised by: i) Financial supervisory authority either it is central bank or outside the central bank, ii) Deposit insurer own supervision.

Banking supervisory powers capture the extent, by which banking supervisor can change the organizational structure and take specific action against bank's directors, managers, auditors and shareholders (Barth et al., 2006). [7]

Moreover, the enactment of EDI enhances the risk-taking of banks, so this provides ground for policymakers to allocate additional supervisory authority to deposit insurer to ensure bank's solvency and control their risk-taking activities.

This is an important gap in the literature, because economic theory suggests that the benefits and costs of deposit insurance may vary with economic conditions. In other words, although deposit insurance can increase moral hazard and make the financial system more vulnerable to crises during economic prosperity, it can also increase depositors' confidence and reduce contagion during turbulent times (such as the recent global financial crisis). Therefore, the net impact of deposit insurance on bank risk and stability depends on whether the benefits of deposit insurance exceed its costs.

\section{Impact of deposit insurance on banking stability}

It is recognized that the guarantee system represents a double-edged sword, playing a preventive role against banking panics, but it can also be a channel for the role of preventing bank panics, but it can also be a channel for the transmission of risk by insuring banks (Cull, Senbet and Sorge, 2001).[8]

As a form of banking regulation, deposit insurance achieves the objective of the supervisory authorities, especially in the event of a disruption of the financial system. financial system. Depositors are often small investors or savers who lack information about the financial situation of their bank.

This asymmetry of information leads to a lack of confidence in the bank on the part of these depositors. Indeed, they do not perfectly observe the actions taken by the management to reimburse them, either by selling assets or by increasing equity. In this case, the deposit insurance protects these small savers by guaranteeing their deposits and in case of bankruptcy of the bank, it reimburses them.

Indeed, depositors, in emerging countries, typically, react sensitively to the security of their deposits, thus to the security of their deposits, so an increase in coverage has an immediate positive impact on the immediate positive impact on agents' perception of the safety of their deposits and the credibility of the credibility of domestic currency (Prean and Stix, 2011).[9]

Depositors' lack of information about the quality of the assets and credits granted by their bank can lead to depositor panic. Indeed, in the event of an economic recession, depositors cannot know whether their bank is among those that may fail. Therefore, they will withdraw their funds regardless of whether they belong to good or bad banks.

According to Bryant (1980),[10] in the absence of deposit insurance, asymmetric information and risky assets are considered necessary for bank runs to occur.

If banks apply the sequential service constraint to repay depositors that is, they apply the "first come, first served" rule, savers will have more incentive to withdraw the first will have a greater incentive to withdraw first. As a result, there will be a rush of depositors and massive withdrawals of funds leading to a banking panic. Here, the role of of deposit insurance persists as a stabilizer of the banking system, i.e., it banks from the rush of depositors. 
In addition, central banks play the role of "bank of banks". They can thus They can thus act to avoid runaway flows by playing on the refinancing facilities they grant to commercial banks. refinancing facilities they grant to commercial banks. In this case, the intervention of the public authorities aims to prevent the risk from turning into a major systemic crisis. systemic crisis. Therefore, central banks act by providing liquidity.

This is what is called their "lender of last resort" function. They and the governments also intervene to governments also intervene to prevent the emergency shutdown of banks and financial institutions and financial institutions whose bankruptcy would cause too many negative effects in a chain (devaluation of negative chain effects (devaluation of assets, spread of mistrust).

There are 112 countries which have been adopted the Explicit Deposit Insurance (EDI) to decrease the likelihood of bank-run (Demirgüç-Kunt, Kane, \& Laeven, 2015).[11]

Although, the bank-run situation arises when depositors have low/no confidence in the banking system but depositor's confidence in the banking sector went up by the assurance of deposit insurance (Prean \& Stix, 2011).

\section{Deposit insurance as a trigger for a systemic crisis}

While the creation of the deposit insurance system was intended to be a remedy for the banks' bad experience banks after they had a bad experience with the Great Depression that took place, it can be a source of the Great Depression, it can be a source of problems for the financial system.

Being insured, depositors will no longer have any interest in monitoring them and banks will thus invest in riskier projects. On this theoretical point, the banking literature clearly states that deposit insurance creates a moral hazard problem that results in excessive risk-taking.

The studies of Demirgüç-Kunt and Detragiache (2002) [12] showed that the probability of having a banking crisis becomes high following the appearance of moral hazard in banks in the presence of deposit insurance. Indeed, it causes low capital buffers of banks.

In addition, deposit insurance reduces the rate of return and mitigates market discipline in risk taking (Demirgüç-Kunt and Huizinga, 2004),[13] as well as allows the banking system to increase the risk of default by increasing the asset risk and leverage effect (Calomiris and Chen, 2016).[14]

This is a major drawback that manifests itself in the change of the bank's behavior after insuring the deposits, i.e., the bank tends to take excessive risks.

In fact, economic agents are encouraged to adopt a less prudent behavior compared to a situation where they would not have been the situation in which they would not be insured. The opposite effect to the one expected occurs the financial sector becomes more fragile.

From the point of view of savers, this moral hazard problem lies in the choice of the bank with which they wish to invest their assets, while the to invest their assets, while at the level of the banks, it concerns the choice of investment investment strategy for the funds collected. In other words, depositors know that they will not bear losses in the event of a losses in the event of a bank failure, thus, the hypothesis of a banking panic, where depositors of a banking panic, where depositors withdraw their deposits massively, as a way of sanctioning the bank, will not take place. Thus, in this case, deposit insurance weakens market discipline and more particularly the discipline of depositors.

Oliynyk et al. (2017) [15] considered the issues of moral hazard compensation in the aspect of life insurance and death insurance.

\section{Related literature}

This paper is based on several strands of the literature. Starting with the contribution of Arrow, (1971) [16] defines the moral hazard as a state when banks take risk and the deposit insurer tolerates consequence of bank's risk-taking. In compliance with economic theory, bank's risk-taking went up after the enactment of EDI (Ross, 1973).[17] So, deposit insurer's supervisory department is employed 
for surveillance and it performs remedial measure to reduce adverse consequence (Miles, 2012). This risk taking is prevailed in the absence of suitable supervision of policymakers while strong supervision of the banking system may limit the bank's risk-taking (Shehzad \& Haan, 2015). [18]

Official Supervisory Powers (OSP) define the powers that are granted to the financial supervisor to take corrective actions to avoid complications, align banks with regulation (Barth et al., 2006). However, strengthening of official supervisory power is positively associated with high financial performance where banking supervisor operated independently (Barth et al., 2013), and increased the bank's soundness (Doumpos et al., 2015).[19]

Furthermore, supervisory powers of a deposit insurer include the authority, to intervene in the bank's activities, to withdraw a bank's insurance coverage, to take lawful act for violating the laws, \& guidelines against the bank's directors and officials (Barth et al., 2013). Moreover, the deposit insurer's power to remove insurance coverage is considered as closing a bank, because the bank who does not offer insurance coverage on their deposits will find it difficult to stay in business (Aysan et al., 2017). [20]

The centralization of "lender of last resort" and the bank's supervisory function to a financial regulator leads to the excessive forbearance to close a bank at the positive level of its capital. Thus, the banks will invest in the sub-optimal loans, but the provision of supplementary supervisory authority to a deposit insurer may improve this problem in the presence of financial supervisory authority. So, in the multi-regulatory environment, where the central bank is working as "lender of last resort" and the banking supervisor, it is beneficial to assign additional supervisory powers to the deposit insurer (Kahn $\&$ Santos, 2005). These distortions provide the rationale to grant additional supervisory powers to deposit insurer in order to ensure bank's solvency and control the risk-taking behavior stimulated by the implementation of deposit insurance.

Conversely, the arguments against the provision of supervisory powers to a deposit insurer suggest that deposit insurer's supervisor may use their powers to extract the kickback, appeal campaign donation to get advantage their favored constituents (Barth et al., 2006). Therefore, it suggests the overlapping of regulations by two supervisors that can produce conflicts for a bank on the basis of their objectives and requirements. So, this justifies policymakers not to allocate the additional supervisory powers to a deposit insurer.

There are ample arguments which favour to allocate/not-allocate the additional supervisory powers to a deposit insurer, while supervisory powers allocated to the deposit insurer deviates in EDI espoused nations (Barth et al., 2013). However, limited number of studies estimated that either to assign additional supervisory authority to a deposit insurer which more likely to decline the risk-taking of banks adopted by explicit deposit insurance. The economic theory supports the view that deposit insurer's supervisory framework can monitor the bank behaviour and take remedial act to bring into line the actions of banks with the goals of deposit insurer.

According to Cull et al., (2005) [21] generous deposit insurance negatively affects the development and growth of the financial system across countries, similarly, Demirgüç-Kunt et al (2014) concluded that the fragility of the banking system, in the years leading to the subprime crisis, was the result of the behavior of banks, belonging to systems adopting deposit insurance, towards risky assets.

In addition, politicized prudential regulation and supervision can reduce the ability to control risktaking by protected banks. In fact, prudential requirements do not have identifiable effects on systemic risk (Barth et al., 2006), and regulatory failure is a consequence of market-based policy that is subject to increased prudential regulation and the safety net.

The increase in bank size due to consolidation exacerbates the Too Big To Fail issue, as the number of large institutions whose failure would expose the financial system to systemic risk increases. Indeed, the Too Big To Fail principle increases the moral hazard for financial institutions that benefit from an extension of public safety. 
Knowing that the institution is subject to bailout in all circumstances, creditors have little incentive to monitor it and withdraw their funds when it takes too much risk. As a result, large interconnected financial institutions are more likely to engage in high-risk activities and increase the likelihood of financial crises (Mishkin, 2010).[22]

Demirgüç-kunt and Detragiache (2002) have shown that explicit deposit insurance schemes tend to facilitate the occurrence of a crisis. In fact, their study of countries with explicit deposit insurance and countries without such insurance showed that for the former countries the risk of crisis is higher.

Calomiris and Jaremski (2016) [23] provide a comprehensive background for the economic and political theories of deposit insurance and conclude that deposit insurance generally tends to increase systemic risk rather than reduce it.

\section{Conclusion}

Generally, ensuring the stability of the financial system is the primary economic concern of any government. economic concern of any government. The failure of a large bank or several bank failures in one country can bank failures in a country can cause a sudden contraction of the money supply or the failure of the payment system the payment system, this can lead to a serious disruption of the economy with real or with real or implied obligations for the government.

Economic theory suggests that the benefits and costs of deposit insurance may vary with economic conditions. In other words, although deposit insurance can increase moral hazard and make the financial system more vulnerable to crises during economic prosperity, it can also increase depositors' confidence and reduce contagion during turbulent times (such as the recent global financial crisis).

\section{References}

[1] Menrad, M. (2020). Systematic review of omni-channel banking and preview of upcoming developments in Germany. Innovative Marketing, 16(2), 104-.125.

[2] Golab, A., Jie, F., Powell, R., \& Zamojska, A. (2018). Cointegration between the European Union and the selected global markets following Sovereign Debt Crisis. Investment Management and Financial Innovations, 15(1), 35-45.

[3] Polina Kuznichenko, Serhiy Frolov, Volodymyr Orlov and Oleksii Boiko (2021). European Deposit Insurance Scheme implementation: pros and cons. Banks and Bank Systems, 16(1), 116-126. doi:10.21511/bbs.16(1).2021.11

[4] Anginer, D., A. Demirgüç-Kunt, and M. Zhu, (2014), « How Does Deposit Insurance Affect Bank Risk? Evidence from the Recent Crisis », Journal of Banking and Finance; also World Bank Policy Research Paper, WPS6289.

[5] Demirgüç-Kunt, A., and E. Detragiache, (2002), « Does Deposit Insurance Increase Banking System Stability? An Empirical Investigation », Journal of Monetary Economics, Vol. 49, No. 7, pp. 1373-1406.

[6] Barth, J.R., Lin, C., Ma, Y., Seade, J., Song, F.M., 2013. Do bank regulation, supervision and monitoring enhance or impede bank efficiency? J. Bank. Finance 37, 2879-2892.

[7] JAMES R. BARTH, GERARD CAPRIO, JR and Ross LEVINE. Rethinking Bank Regulation: Till Angels Govern. Cambridge University Press, New York. 2006

[8] Cull, R., L.W. Senbet, \& M. Sorge, (2001), «The effect of deposit insurance on financial depth: A cross-country analysis », The Quarterly Review of Economics and Finance 42 (2002) 673694.

[9] N. Prean and H. Stix, "The Effect of Raising Deposit Insurance Coverage in Times of Financial Crisis-Evidence from Croatian Microdata," Economic Systems, Vol. 35, No. 4, 2011, pp. 496-511. doi:10.1016/j.ecosys.2011.01.004.

[10] Bryant, J. (1980) A Model of Reserves, Bank Runs, and Deposit Insurance. Journal of Banking and Finance, 4, 335-344. 
[11] Demirgüç-Kunt, Kane et Laeven, (2015), « Deposit Insurance Database ». Journal of Banking and Finance,

[12] Demirguc-Kunt, A., Detragiache, E., (2002). « Does deposit insurance increase banking system stability? An empirical investigation ». Journal of Monetary Economics 49 (7), 1373-1406.

[13] Demirguc-Kunt, A., Huizinga, H., (2004). « Market discipline and deposit insurance ». Journal of Monetary Economics 51 (2), 375-399.

[14] Calomiris, Charles W. and Sophia Chen. (2016). "The spread of deposit insurance and the global rise in bank leverage since the 1970s. » Working paper.

[15] Oliynyk, V., Zhuravka, F., Bolgar, T., \& Yevtushenko, O. (2017). Optimal control of continuous life insurance model. Investment Management and Financial Innovations, 14(4), 21-29.

[16] Arrow, K.J. (1971) The Theory of Risk Aversion. In: Helsinki, Y.J.S., Ed., Aspects of the Theory of Risk Bearing, Reprinted in Essays in the Theory of Risk Bearing, Markham Publ. Co., Chicago, 90-109.

[17] Ross, Stephen A, 1973. "The Economic Theory of Agency: The Principal's Problem," American Economic Review, American Economic Association, vol. 63(2), pages 134-139, May

[18] Shehzad, Choudhry Tanveer \& De Haan, Jakob, 2015. "Supervisory powers and bank risk taking," Journal of International Financial Markets, Institutions and Money, Elsevier, vol. 39(C), pages 15-24.

[19] Doumpos, Michael \& Gaganis, Chrysovalantis \& Pasiouras, Fotios (2015): Central bank independence, financial supervision structure and bank soundness: An empirical analysis around the crisis. Journal of Banking \& Finance, Elsevier, vol. 61(S1), pages 69-83.

[20] Ahmet F. Aysan \&amp; $\quad$ Mustafa Disli \&amp; $\quad$ Meryem Duygun \&amp; Huseyin Ozturk (2017): Islamic Banks, Deposit Insurance Reform, And Market Discipline: Evidence From A Natural Framework. Journal of Financial Services Research, Springer;Western Finance Association, vol. 51(2), pages 257-282, April.

[21] Cull, Robert \& Senbet, Lemma W \& Sorge, Marco (2005): Deposit Insurance and Financial Development. Journal of Money, Credit and Banking, Blackwell Publishing, vol. 37(1), pages 43-82, February.

[22] Frederic S. mishkin (2010): Over The Cliff: From the Subprime to the Global Financial Crisis. NBER Working Papers 16609, National Bureau of Economic Research, Inc.

[23] Charles W. Calomiris \& Matthew Jaremski, 2016. "Deposit Insurance: Theories and Facts," Annual Review of Financial Economics, Annual Reviews, vol. 8(1), pages 97-120, October. 